\title{
Effect of Manuka Honey on Transforming Growth Factor Beta-I-Induced Extracelluar Matrix Production in Nasal Polyp Derived Fibroblasts
}

\author{
Bu-Kwan Kil, Bo-Mun Kim, Byung-Jun Kang, Mi-Kyung Ye, and Seung-Heon Shin \\ Department of Otolaryngology-Head and Neck Surgery, School of Medicine, Catholic University of Daegu, Daegu, Korea
}

\section{마누카꿀이 TGF- $\beta 1$ 에 의한 비용 섬유모세포의 세포외기질 생성에 미치는 영향}

길부관 · 김보문 · 강병준 · 예미경 · 신승헌

대구가톨릭대학교 의과대학 이비인후과학교실

\author{
Received September 28, 2018 \\ Revised December 26, 2018 \\ Accepted January 29, 2019 \\ Address for correspondence \\ Seung-Heon Shin, MD, PhD \\ Department of Otolaryngology-Head \\ and Neck Surgery, School of \\ Medicine, Catholic University of \\ Daegu, 33 Duryugongwon-ro 17-gil, \\ Nam-gu, Daegu 42472, Korea \\ Tel $+82-53-650-4530$ \\ Fax $+82-53-650-4533$ \\ E-mail hsseung@cu.ac.kr
}

Background and Objectives Manuka honey has anti-microbial, anti-inflammatory, and anti-proliferative action with a high concentration of methylglyoxal compound. It is also effective in killing Staphylococcus aureus biofilm and effective for the acute exacerbation of chronic rhinosinusitis. The aim of this study was to determine the anti-fibrotic effect of manuka honey in nasal polyp fibroblasts.

Materials and Method Primary nasal fibroblasts were isolated from nasal polyps and treated with transforming growth factor-beta 1 (TGF- $\beta 1$ ). To determine the anti-fibrotic effect of manuka honey, fibroblasts were pre-treated with various concentration of the honey. Reverse transcription-polymerase chain reaction and western blot analysis were then performed to determine $\alpha$-smooth muscle actin ( $\alpha$-SMA), collagen type I, and matrix metalloproteinase- 9 (MMP-9) messenger ribonucleic acid (mRNA) expression and protein production in nasal polyp fibroblasts. Phosphorylated Smad ( $p$ Smad) 2/3 and phosphorylated adenosine monophosphate-activated protein kinase ( $p$ AMPK) were then determined by western blotting.

Results TGF- $\beta 1$ stimulation increased $\alpha$-SMA, collagen type I, and MMP-9 mRNA expression and protein production in nasal polyp fibroblasts. Manuka honey effectively suppressed $\alpha$-SMA, collagen type I, and MMP-9 mRNA expression and protein production. Its inhibitory role on TGF- $\beta 1$ induced myofibroblast differentiation and its extracellular matrix production was associated with Smad2/3 and AMPK pathway.

Conclusion Manuka honey can inhibit TGF- $\beta 1$ induced myofibroblast differentiation, collagen type I, and MMP-9 production in nasal fibroblasts. These results suggest that manuka honey might be a useful candidate for the inhibition of nasal polyp formation if further studies in vivo were accompanied.

Korean J Otorhinolaryngol-Head Neck Surg 2019;62(6):336-42

Key Words Extracellular matrix · Fibroblast · Manuka honey · Nasal polyp · Transforming growth factor beta.

\footnotetext{
서 론

만성 비부비동염은 비부비동 점막에 발생하는 염증성 질

This is an Open Access article distributed under the terms of the Creative Commons Attribution Non-Commercial License (https://creativecommons.org/licenses/by-nc/4.0) which permits unrestricted non-commercial use, distribution, and reproduction in any medium, provided the original work is properly cited.
}

환으로 알레르기, 점액섬모수송 장애, 해부학적 혹은 면역학 적 이상 등이 관여하는 다인성 질환으로 발병기전에 대한 논 란이 지속되고 있다. ${ }^{1)}$ 조직내 염증세포의 침윤, 기저막 비후 와 세포외기질의 축척은 만성 비부비동염의 특징적 소견으 로 비용을 동반하지 않은 경우 matrix metalloproteinase-9 (MMP-9), tissue inhibitors of matrix metalloproteinase-1 
(TIMP-1), transforming growth factor-beta(TGF- $\beta$ )가 증 가되나 비용을 동반한 경우 MMP-9은 증가하지만 TIMP-1 과 TGF- $\beta$ 는 상대적으로 낮게 발현된다. ${ }^{2,3}$ 하지만 비용조직 에서 TGF- $\beta$ 의 발현이 증가되어 있다는 보고도 있는데 이는 비용조직 내 호산구, vascular endothelial growth factor 등이 관여하고 있다. ${ }^{4,5)} \mathrm{TGF}-\beta$ 는 조직내 섬유모세포의 분화와 세 포외기질 단백의 합성을 유도하여 만성 비부비동염과 비용 형성에 관여한다.

벌꿀은 기원전부터 감염된 상처나 위장관 질환의 치유와 신 경계 증상 개선 등을 위해 민간에서 사용되어 왔다. 20 세기 에 들어와 벌꿀의 상처 치유 과정에 과학적 근거가 보고 되면 서 다양한 항균, 항염증 효과에 대한 연구들이 진행되었다. ${ }^{67}$ 특히 뉴질랜드 마누카꿀은 세균의 성장을 억제하거나 파괴하 고, 심한 화상이나 당뇨성 궤양 치료 효과를 가지는 등 임상 적 활용 가능성에 대한 연구가 이루어져 왔다. ${ }^{89}$ 마누카꿀에 포함되어 있는 메틸글리옥살(methylglyoxal) 화합물에 의해 항균, 항염증 효과를 가지며, Staphylococcus aureus에 의해 형성된 생물막(biofilm)에 대한 항균효과가 입증되어 만성 비 부비동염의 치료제로서의 활용 가능성이 보고되었다.10)

만성 비부비동염에서 collagen, MMP-9, TIMP-1 등은 조 직 재형성에 중요한 역할을 담당하며 이들은 피부 조직의 재 생에도 관여한다. 즉, 벌꿀이 피부 상처 치유 효과를 가지듯 이 손상된 비부비동 점막의 재형성에도 관여할 것이라는 가 정하에 본 연구를 진행하였다. ${ }^{11)}$ 항염증 효과를 가지는 마누 카꿀이 비용-유래 섬유아세포의 분화와 세포외기질 생성에 미치는 영향을 알아보고자 하였다.

\section{재료 및 방법}

\section{마누카꿀의 준비}

벌꿀은 뉴질랜드 Honey NZ International Ltd(Hamilton, New Zealand)에서 제공한 마누카꿀을 사용하였다. 꿀은 25 $\mathrm{kGy}$ 의 코발트-60 방사선 조사장치에서 발생하는 감마선을 이용하여 소독하였으며, $1.37 \mathrm{~g}$ 의 꿀을 $19 \mathrm{~mL}$ 의 RPMI 1640 (GIBCO, Grand Island, NY, USA)에 섞어 최종 농도 $5 \% \mathrm{v} / \mathrm{v}$ 을 준비하였다. 꿀에 포함되어 있는 꽃가루, 벌 조직 등은 Minisart Sartorius filter(Millipore Corp., Seattle, WA, USA)를 사용하 여 제거하였다. 꿀이 포함하고 있는 효소의 변성과 분해를 방 지하기 위해 실험이 진행될 때까지 어두운 용기에 넣어 $4^{\circ} \mathrm{C}$ 에 보관하였다.

\section{비용 섬유아세포의 분리배양}

섬유아세포는 부비동 내시경수술을 시행한 비용을 동반한
만성 비부비동염 환자 10명(남성과 여성 각 5 명, 평균 연령 38.9 \pm 9.7 세)의 비호산구성 비용조직에서 분리하여 사용하였다. 비용 조직의 특성은 Tokunaga 등'2)이 보고하였던 Japanese Epidemiological Survey of Refractory Eosinophilic Chronic rhinosinusitis score를 기준으로 결정하였다. 연구는 대구가 톨릭대학교병원 임상시험윤리위원회의 승인을 얻어 진행되었 다. 대상자에게는 연구의 목적과 방법 등에 대한 정보를 제공 하고 서면 동의서를 받았다. 만성 비부비동염의 진단은 2012 년도에 발표된 European Position Paper on Rhinosinusitis and Nasal Polyps에서 제시한 기준 ${ }^{13}$ 에 따랐으며, 수술 전 적 어도 4주 이내에 상기도 감염이 있었거나, 항생제나 항히스타 민제의 사용 혹은 경구나 비강 스테로이드제를 사용한 환자, 알레르기를 동반한 환자는 대상에서 제외하였다.

비용조직은 $0.3 \sim 0.5 \mathrm{~mm}$ 의 절편을 만들어 인산완충생리식 염수(phosphate buffered saline, PBS)에 세척 후 $10 \%$ 소태아 혈청, $100 \mathrm{U} / \mathrm{mL}$ 의 penicillin, $100 \mathrm{ug} / \mathrm{mL}$ 의 streptomycin, 1.5 $\mathrm{ug} / \mathrm{mL}$ 의 amphotericin B를 포함하고 있는 Dulbecco's Modified Eagle's Medium F-12(Gibco, Grand Island, NY, USA) 에 넣고, $37^{\circ} \mathrm{C}, 5 \% \mathrm{CO}_{2}$ 에서 배양하였다. 단층을 형성하면 $\mathrm{PBS}$ 로 세척 후 $0.05 \%$ trypsin-ethylene diamine tetraacetic acid (Sigma-Aldrich, St. Louis, MO, USA)로 5분간 처리하여 분 리 배양하였다. 연구에는 3 4세대째 계대배양된 섬유아세포 를 사용하였다.

\section{마누카꿀이 비용 섬유아세포의 세포증식에 미치는 영향}

마누카꿀의 세포독성은 CellTiter-96 ${ }^{\circledR}$ AQueous one solution cell proliferation assay kit(Promega Corp., Madison, WI, USA)를 이용하여 측정하였다. 배양된 섬유아세포에 대 한 세포독성을 확인하기 위하여 $0.5 \%, 2 \%, 5 \%$ 의 꿀로 24 시 간 동안 $37^{\circ} \mathrm{C}, 5 \% \mathrm{CO}_{2}$ 에서 처리 후, 배양액을 $\mathrm{PBS}$ 로 3 회 세 척하였다. 세포 증식의 확인을 위하여 tetrazolium 합성물 2 $\mathrm{mL}$ 과 phenazine ethosulfate $100 \mathrm{uL}$ 를 섞은 후 well당 $20 \mathrm{uL}$ 의 혼합용액을 투여하여 1시간동안 배양 후 $490 \mathrm{~nm}$ 의 ELISA reader(Modecular Devices, San Jose, CA, USA)를 사용하 여 흡광도를 측정하였다.

\section{마누카꿀이 비용 섬유아세포의 $\alpha$-SMA, collagen type I, MMP-9 mRNA 발현에 미치는 영향}

섬유아세포의 $\alpha$-smooth muscle actin( $\alpha$-SMA), collagen type I, MMP-9 messenger ribonucleic acid(mRNA) 발현을 확인하기 위하여 섬유아세포를 $0.5 \%, 1 \%, 2 \%$ 의 마누카꿀로 1 시간 처리하거나 전처리 없이 TGF- $\beta 1$ 로 24시간 배양 후 세 포를 분리하였다. 세포가 녹아있는 Trizol ${ }^{\circledR}(\mathrm{GIBCO})$ 용액을 가 
압 멸균된 RNA 미세원심 분리시험관에 넣고 $200 \mu \mathrm{L}$ 의 클로 로포름을 첨가 후 흔들어 잘 섞이게 하고 $13000 \mathrm{rpm}$ 으로 15 분간 원심 분리하여 상층액에서 $500 \mu \mathrm{L}$ 를 취하였다. 상층액 과 동량의 isopropanol을 넣고 잘 섞어 10 분간 방치 후 13000 $\mathrm{rpm}$ 으로 10분간 원심 분리하였다. 얻어진 RNA 침사를 $70 \%$ 에틸알코올로 세척한 후 diethyl pyrocarbonate를 처리한 증 류수 $10 \mu \mathrm{L}$ 로 RNA 침사를 녹여서 RNA를 추출하였다.

추출한 RNA를 대상으로 reverse transcription system (Promega Corp.)을 이용하여 cDNA를 합성하였다. 역전사 중 합효소연쇄반응(reverse transcription-polymerase chain reaction, RT-PCR)의 조건은 다음과 같다. $5 \mathrm{mM} \mathrm{MgCl}_{2}, 10 \mathrm{mM}$ Tris $-\mathrm{HCl}\left(\mathrm{pH} 9.0,25^{\circ} \mathrm{C}\right), 50 \mathrm{mM} \mathrm{KCl}, 0.1 \%$ triton $\mathrm{X}-100$, 각 각의 dNTP $1 \mathrm{mM}, 1 \mathrm{U} / \mu \mathrm{L}$ Ribonuclease inhibitor, $20 \mathrm{U}$ AMV reverse transcriptase, $0.5 \mu \mathrm{g}$ oligo(dT)15 primer로 구성된 중합효소연쇄반응 시약에 RNA $9.5 \mu \mathrm{L}$ 를 주입하여 총 $20 \mu \mathrm{L}$ 를 DNA thermal cycler 480(PE Applied Biosystems, Foster City, CA, USA)으로 증폭하였다. $25^{\circ} \mathrm{C}$ 에서 10 분간 반응시킨 뒤 $42^{\circ} \mathrm{C}$ 에서 60 분간 방치하고 $72^{\circ} \mathrm{C}$ 에서 5 분간 방치하여 역전 사효소를 무력화시킨 뒤 $4^{\circ} \mathrm{C}$ 로 냉장시켰다.

합성된 cDNA를 대상으로 $\alpha-\mathrm{SMA}$, collagen type I, MMP-9 과 $\beta$-actin의 정량적 중합효소연쇄반응을 MJ Mini personal Thermal cycler(Bio-Rad, Hercules, CA, USA)로 실시하였다. 중합효소연쇄반응에 사용되는 시약은 TB Green ${ }^{\mathrm{TM}}$ Premix $\mathrm{Ex} \mathrm{Taq}^{\mathrm{TM}}$ (Takara Bio Inc., Otsu, Japan)을 사용하였다. DNA 가 증폭되면 SYBR ${ }^{\circledR}$ green(Applied Biosystems, Waltham, $\mathrm{MA}, \mathrm{USA}$ )과 결합하여 형광을 발생, 중합효소연쇄반응의 각 주기마다 닫혀져 있는 시험관의 마개를 통하여 형광의 세기 를 측정함으로써 중합효소연쇄반응 산물을 정량적으로 나타 낼 수 있다. 즉, 주입한 DNA 양이 많을수록 형광이 처음으로 검출되는 연쇄반응 주기의 시점이 빨라지고 이를 threshold cycle 수로 나타낸다. $\alpha$-SMA, collagen type I, MMP-9과 $\beta-$ actin의 발현을 위해 $95^{\circ} \mathrm{C}$ 에서 1 분간 반응시킨 다음, 변성 $95^{\circ} \mathrm{C}$
15 초, 결합 $54 \sim 60^{\circ} \mathrm{C} 15$ 초, $72^{\circ} \mathrm{C} 45$ 초로 40 회 동안 증폭하였다. 사용한 primer의 유전자 위치, 염기서열, 증폭 산물의 크기는 Table 1과 같다.

\section{마누카꿀의 비용 섬유아세포 $\alpha-S M A$, collagen type I, MMP-9 단백 발현에 미치는 영향}

섬유아세포의 단백발현은 각각의 조건으로 배양된 세포에서 western blot을 이용하여 측정하였다. 세포는 $100 \mathrm{uL}$ 의 RIPA 완충액(150 mM NaCl, $1 \% \mathrm{NP} 40,0.5 \%$ deoxycholate, $0.1 \%$ sodium dodecyl sulfate, and $50 \mathrm{mM}$ Tris- $\mathrm{Cl}$ )을 이용하여 단백질을 분리하였다. 분리된 단백질은 $\mathrm{BCA}$ protein assay reagent kit(Pierce Biotechnology, Rockford, IL, USA)를 이 용하여 측정하였다. 정량한 sample을 같은 양으로 NuPAGE 4 12\% Bis-Tris gel(Invitrogen)에 전기영동한 후 Xcell Surelock(Invitrogen)을 이용하여 nitrocellulose membrane 에 1시간 transfer하였다. Transfer가 끝난 membrane을 세척 한 후, membrane blocking solution(Invitrogen)에서 1시 간 동안 처리하였다. 준비된 membrane에 $\alpha-\mathrm{SMA}$, collagen type I, MMP-9과 GAPDH 항체(Santa Cruz Biotechnology, Santa Cruz, CA, USA)를 1:1000으로 희석하여 처리하고 $4^{\circ} \mathrm{C}$ 에서 밤새 반응시켰다. 다음날 goat anti-rabbit HRP-conjugated된 이차 항체(Santa Cruz Biotechnology)를 1:3000 으로 희석하여 상온에서 1시간 반응시켰다. 이 후 SuperSignal West Pico Chemiluminescent Substrate(Pierce Biotechnology) 이용하여 발색시켜 Gel Doc XR+(Bio-Rad)로 단백 발현량을 확인하였다.

\section{마누카꿀이 비용 섬유아세포 Smad 2/3와 adenosine monophosphate-activated protein kinase(AMPK) 발현에 미치는 영향}

비용 섬유아세포에서 발현하는 phosphorylated Smad $(p S-$ mad) 2/3과 AMPK는 western blot을 이용하여 측정하였다.

Table 1. Sequencing data for the primer for RT-PCR analysis of tight and adherens junction of nasal epithelial cells

\begin{tabular}{llc}
\hline \multicolumn{1}{c}{ Targe gene } & \multicolumn{1}{c}{ Sequences } & Produce size \\
\hline$\alpha$-SMA & Forward 5'-ATAGAACATGGCATCATCACCAAC-3' & 82 bp \\
Collagen type I & Reverse 5'-GGGCAACACGAAGCTCATTGTA-3' & 198 bp \\
& Forward 5'-GCTTGGTCCACTTGCTTGAAGA-3' & 195 bp \\
MMP-9 & Reverse 5'-GAGCATTGCCTTTGATTGCTG-3' & 248 bp \\
B-actin & Forward 5'-ATTTCTGCCAGGACCGCTTCTACT-3' & \\
& Reverse 5-CAGTTTGTATCCGGCAAACTGGCT-3 & \\
\hline
\end{tabular}

a-SMA: a-smooth muscle actin, MMP-9: matrix metalloproteinase-9, RT-PCR: reverse transcription-polymerase chain reaction 
섬유아세포를 마누카꿀로 1 시간 전처리하거나 전처리 없이 $\mathrm{TGF}-\beta 1$ 로 6시간 배양 후 세포를 획득하였다. 이들 전사인자 의 발현은 위와 동일한 방법으로 western blot을 이용하여 측 정하였다.

\section{통계 분석}

각각의 실험은 5 회 이상 반복하여 그 결과를 얻고자 하였 으며 마누카꿀의 세포독성은 1 개 요소 분산값(one factor repeated measure analysis)을 이용하였으며, 비강 섬유아세포 의 세포외기질과 전사인자 발현은 Kruskal-Willis test를 사 용하여 분석하였다(SPSS ver. 21.0, IBM Corp., Armonk, $\mathrm{NY}, \mathrm{USA}$ ). 통계학적 유의수준은 0.05로 하였다.

\section{결 과}

\section{마누카꿀의 섬유아세포에 대한 세포독성}

$0.5 \%, 2 \%, 5 \%$ 의 마누카꿀과 섬유아세포를 1시간, 6 시간, 24 시간 배양하였으며, $5 \%$ 의 농도에서 배양 6시간(27\%)과 24 시간(38\%)에서 세포분화가 감소하는 독성을 보여 이후 진행되 는 실험은 $2 \%$ 이하의 농도에서 시행되었다(Fig. 1).

\section{마누카꿀이 비용 섬유아세포 $\alpha-\mathrm{SMA}$, collagen type I,} MMP-9 mRNA와 단백 발현에 미치는 영향

섬유아세포를 $0.5 \%, 1 \%, 2 \%$ 의 마누카꿀로 전처리 하거나, 꿀로 처리하지 않은 상태에서 $5 \mathrm{ug} / \mathrm{mL}$ 의 TGF- $\beta 1$ 와 배양 후 mRNA는 RT-PCR을 이용하여, 단백 생성은 western blot 분 석을 이용하여 확인하였다. TGF- $\beta 1$ 은 섬유아세포의 $\alpha-\mathrm{SMA}$, collagen type I, MMP-9 mRNA와 단백 발현을 증가시켰 고, $\mathrm{TGF}-\beta 1$ 에 의한 $\alpha-\mathrm{SMA} \mathrm{mRNA}$ 발현은 마누카꿀 $2 \%$ 에

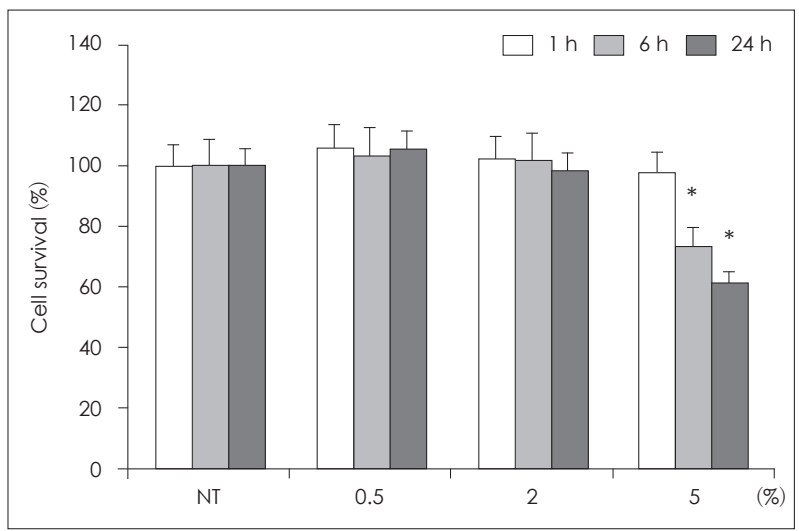

Fig. 1. Effect of manuka honey on proliferation of nasal polyp fibroblasts. Fibroblasts were treated with various concentrations of manuka honey for 24 hours. $5 \%$ of acacia honey inhibited the proliferation of nasal fibroblasts. ${ }^{*} p<0.05$. NT: non-treated control.
서 40.5\%, collagen type I과 MMP-9 mRNA는 마누카꿀 $0.5 \%$ 에서 각각 $51.4 \%$ 와 $51.6 \%$ 로 강하게 발현이 억제되었다. 섬유아세포의 단백 생성은 $\alpha-\mathrm{SMA}$ 와 collagen type I의 경 우 마누카꿀 $1 \%$ 에서 각각 $42.6 \%$ 와 $40.5 \%, \mathrm{MMP}-9$ 은 $2 \%$ 에 서 $42.1 \%$ 로 가장 많이 억제되었다. 섬유아세포를 전처리한 마 누카꿀의 농도가 mRNA와 단백 생성 억제 효과에 유의한 영 향을 미치지는 않았다(Fig. 2).

\section{마누카꿀이 비용 섬유아세포 $p \operatorname{Smad} 2 / 3$ 와 $p \mathrm{AMPK}$ 발현에 미치는 영향}

섬유아세포를 $0.5,1,2 \%$ 의 마누카꿀로 전처리 하거나, 꿀 로 처리하지 않은 상태에서 $\mathrm{TGF}-\beta 1$ 와 배양 후 $p \operatorname{Smad} 2 / 3$ 와 $p \mathrm{AMPK}$ 를 western blot 분석을 이용하여 확인하였다. TGF$\beta 1$ 은 섬유아세포의 $p \operatorname{Smad} 2 / 3$ 의 발현을 유의하게 증가시켰 으며, 마누카꿀로 전처리하는 경우 각각의 농도에서 $p \mathrm{Smad}$ $2 / 3$ 발현이 유의하게 감소하였다. $p \mathrm{AMPK}$ 의 경우 $\mathrm{TGF}-\beta 1$ 에 의해 유의한 발현 증가는 없었으나 마누카꿀 $0.5 \%$ 와 $1 \%$ 로 처리한 경우 음성대조군에 비해 약 2.4배 이상 발현이 증 가하였으며, $\mathrm{TGF}-\beta 1$ 으로 처리한 경우 보다 1.67 배 이상 증가 하였다(Fig. 3).

\section{고 찰}

만성 비부비동염은 국소 염증반응에 의한 조직내 염증세포 의 침윤과 세포외기질의 축적에 의한 조직재형성을 특징으 로 한다. $\mathrm{TGF}-\beta$ 는 면역조절 기능을 가지고 있으며 근섬유모 세포의 분화와 세포외기질 생성에 중요한 역할을 담당한다. 본 연구에서도 $\mathrm{TGF}-\beta 1$ 과 함께 배양한 비용 섬유아세포에서 $\alpha-\mathrm{SMA}$, collagen type I, MMP-9의 mRNA와 단백 발현이 증가하였으며, 마누카꿀로 전처리 한 경우 이들 mRNA와 단 백 발현이 유의하게 감소함을 확인할 수 있었다. 이는 마누카 꿀이 비용 조직의 근섬유모세포(myofibroblast) 분화와 세포 외기질 생성을 억제할 수 있음을 의미하는 것이다. 본 연구에 서는 섬유아세포를 비용 조직에서 분리 배양하여 사용하였 는데, 이는 정상인과 비용 환자의 비강 섬유아세포의 세포외 기질 생성과 그 발현 기전에 차이가 없다는 기존의 연구 결과 를 근거로 하였다. ${ }^{14)}$

벌꿀의 삼투압, 수소이온 농도, 과산화효소(peroxidase) 활 성도, 메틸글리옥살 함량 등에 의해 면역학적 특성이 결정되 는데, 인체내에서 면역 억제 뿐만 아니라 면역 활성화를 유도 할 수 있다. ${ }^{914)}$ 대부분의 벌꿀은 지질다당류를 포함하고 있으 나 면역학적 영향을 미칠 정도의 양은 아니며, 벌꿀에 포함되 어 있는 꽃가루와 꿀 처리과정의 오염 문제를 해결하기 위해 

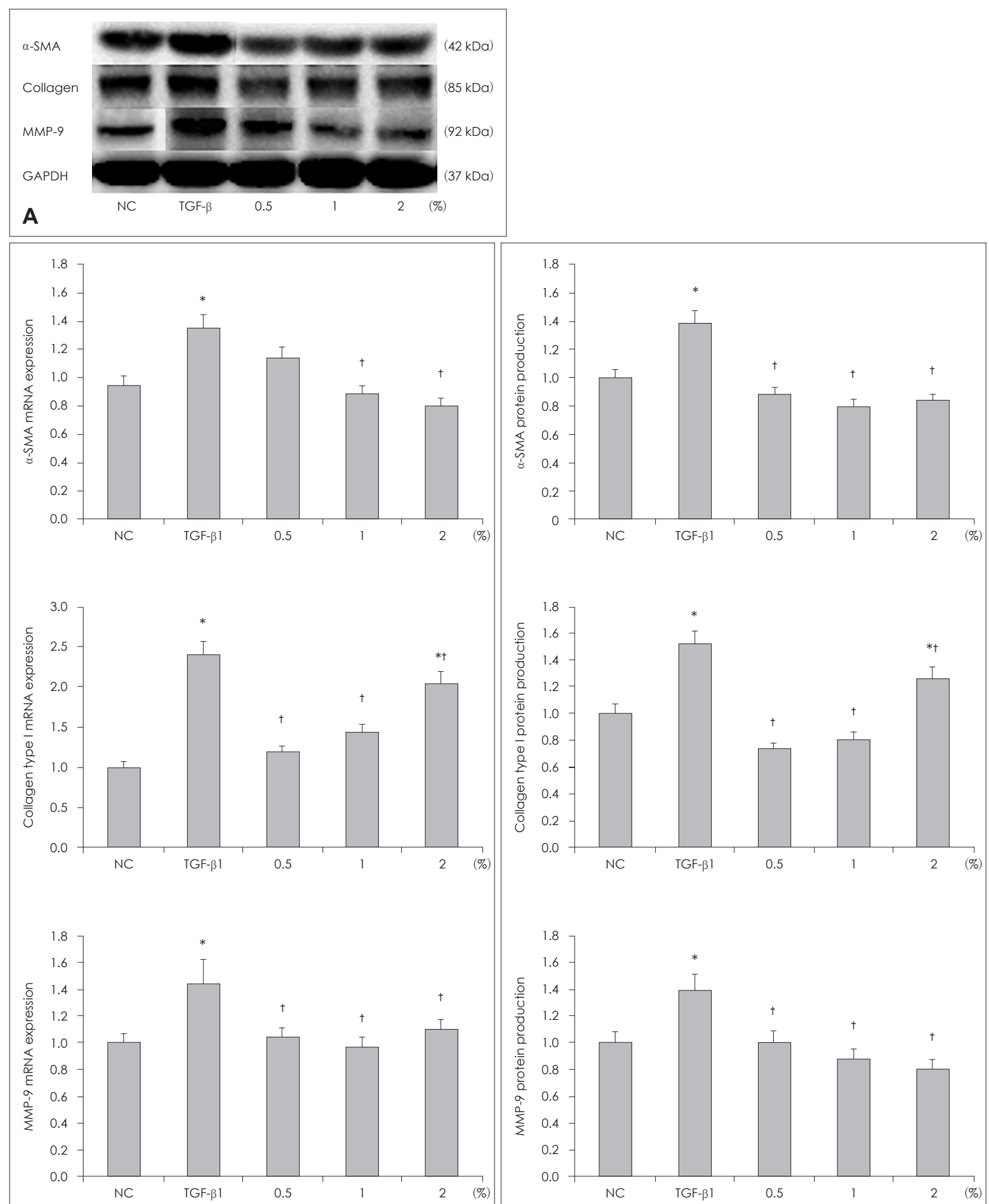

B

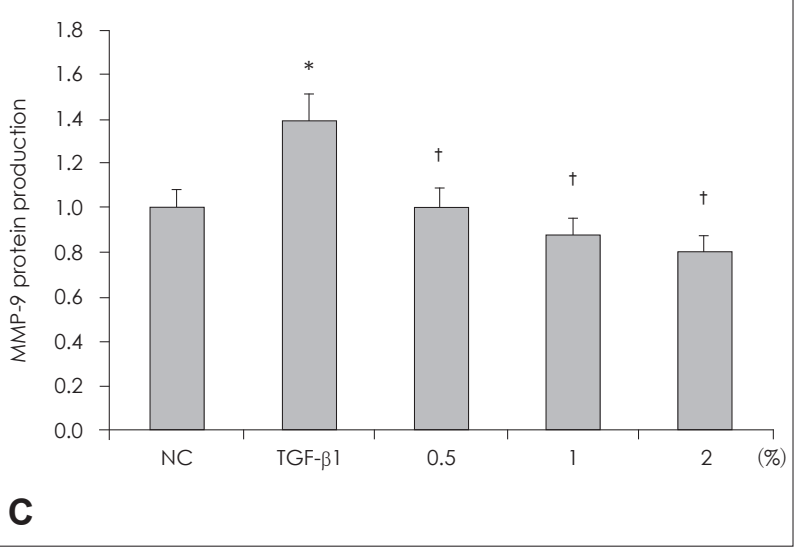

Fig. 2. Effect of acacia honey on expression of TGF- $\beta 1$ induced $\alpha-S M A$, collagen type $I$, and MMP-9 mRNA (B) and protein (C) in nasal polyp fibroblasts. TGF- $\beta 1$ induced $\alpha-S M A$, collagen type I, and MMP-9 mRNA and protein expressions were significantly suppressed by manuka honey. A shows representative results of western blot analysis. ${ }^{*} p<0.05$ compared with the negative control, ${ }^{\dagger} p<0.05$ compared with TGF- $\beta 1$ treated group. $\alpha-S M A$ : $\alpha$-smooth muscle actin, GAPDH: TGF- $\beta 1$ : transforming growth factor-beta1, MMP-9: matrix metalloproteinase-9, mRNA: messenger ribonucleic acid, NC: negative control. 


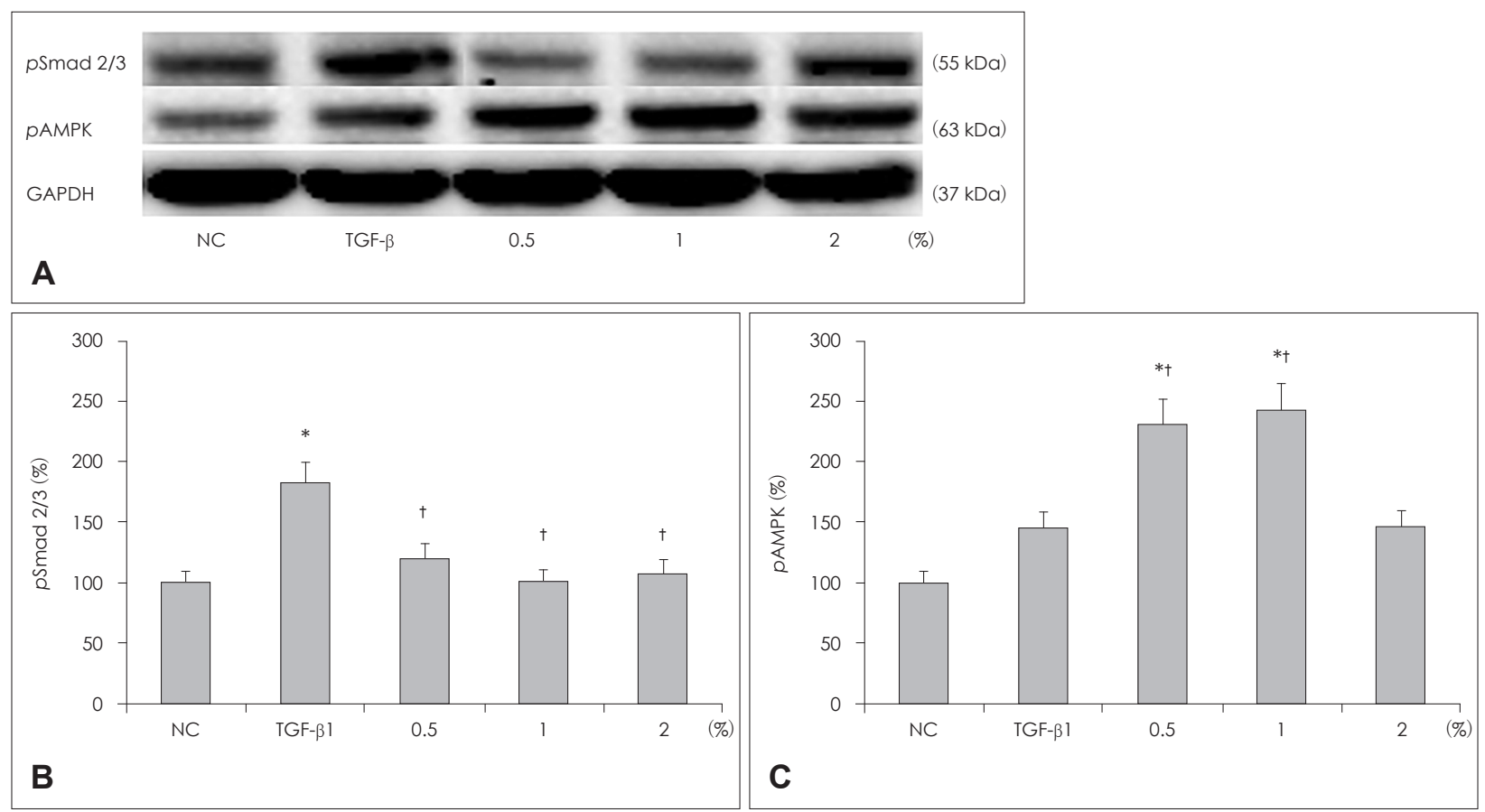

Fig. 3. Effect of manuka honey on $p S m a d 2 / 3$ and $p A M P K$ expression in nasal polyp fibroblasts. $p S m a d 2 / 3$ and $p A M P K$ were measured using western blotting and density analysis. A shows representative results of western blot analysis. TGF- $\beta 1$ induced Smad $2 / 3$ phosphorylation was significantly inhibited by manuka honey (B) and AMPK expression was significantly increased (C) by manuka honey. ${ }^{*} p<0.05$ compared with the negative control, ${ }^{\dagger} p<0.05$ compared with TGF- $\beta 1$ treated group. pSmad 2/3: phosphorylation of Smad 2/3, pAMPK: phosphorylated adenosine monophosphate-activated protein kinase, TGF- $\beta 1$ : transforming growth factor-beta1, NC: negative control.

감마선 조사와 필터 처리 후 사용하였다. 벌꿀의 항균, 항염 증 효과는 조직 재생을 촉진하고, 상피세포를 형성시키며, 반 흔 형성을 최소화 시켜주는 특성을 이용하여 창상치유에 사 용되어 왔으며, 항산화, 항균 등의 특성을 가지고 있다. ${ }^{7-9)}$ 특 히 뉴질랜드에서 생산되는 마누카꿀은 다량의 메틸글리옥살 을 함유하고 있어 강력한 항균, 항염증 효과를 가지고 있어 많은 연구가 이루어져 왔다. ${ }^{10,15)}$ 마누카꿀의 Staphylococcus aureus와 Pseudomonas aeruginosa에 의해 만들어지는 생 물막에 대한 효과를 보고하면서 만성 비부비동염의 치료제 로서의 활용 가능성이 제시 되기도 하였다. ${ }^{16)}$ 이처럼 마누카 꿀의 항염증, 항균 효과에 대한 다양한 보고는 있었으나 조 직재형성에 대한 연구는 부족하여 마누카꿀의 만성 비부비 동염 조직 재형성에 미치는 영향을 확인하기 위하여 본 연구 를 진행하였다.

TGF- $\beta 1$ 은 만성 비부비동염 조직에서 증가되어 있으며, 섬 유아세포의 분화를 유도하고 $\alpha$-SMA과 collagen의 생성을 유도하는 것으로 알려져 있다. ${ }^{17)}$ 이처럼 TGF- $\beta 1$ 은 근섬유모 세포의 마커인 $\alpha-\mathrm{SMA}$ 의 발현을 증가시키고, 세포외기질 단 백의 합성을 통한 조직 재형성을 유도하여 만성 비부비동염, 비용, 기관지 천식과 같은 호흡기 질환의 병태생리에 관여하 게 된다. ${ }^{2,318)}$ 만성 비부비동염의 경우 세포외기질에 두꺼운 콜
라겐 섬유를 형성하고 있는 특징을 가지고 있으며, MMP-9 과 $\mathrm{TGF}-\beta 1$ 이 조직내에서 증가하는 것이 관찰된다. ${ }^{2,3,17)}$ $\mathrm{Smad} 2 / 3$ 의 인산화는 $\mathrm{TGF}-\beta 1$ 에 의한 섬유아세포의 근섬유 모세포로의 분화와 세포외기질 단백 합성에 중요하게 관여 하는 전사인자이다. ${ }^{14)} \mathrm{Smad} 2 / 3$ 은 $\alpha-\mathrm{SMA}$ 의 발현을 증가시 키고, 각종 세포외기질의 생성을 유도하게 된다. $\mathrm{AMPK}$ 는 에 너지대사, 세포 분화와 화학 매개 물질의 생성, 세포자연사와 염 증반응에 관여한다. ${ }^{19)}$ 비용 섬유아세포에서 AMPK가 TGF$\beta 1$ 에 의한 근섬유모세포의 분화를 억제하고 세포외기질 생성 을 억제하는 것으로 보고 되었다. ${ }^{20)}$ 마누카꿀은 $0.5 \%$ 이상의 농도에서 $p \operatorname{Smad} 2 / 3$ 의 발현을 억제하였을 뿐 아니라 $p \mathrm{AMPK}$ 의 발현을 증가시켰다. 이는 마누카꿀이 섬유아세포의 세포 외기질 생성에 관여하는 두 전사인자에 동시에 작용하는 이 중작용(dual action) 효과를 나타내는 것으로 마누카꿀이 강 력한 항섬유화 효과를 가지고 있음을 알 수 있었다. 하지만 $\mathrm{TGF}-\beta 1$ 에 의한 collagen type I이나 MMP-9의 생성 억제 효 과와 전사인자 발현 억제가 마누카꿀의 농도와는 연관성을 보이지 않았다. 향후 마누카꿀의 항섬유화 효과를 얻을 수 있 는 최적의 농도 결정과 마누카꿀에 의한 $\mathrm{Smad} 2 / 3$ 과 $\mathrm{AMPK}$ 의 작용 기전에 대한 추가적인 연구가 필요할 것이다.

마누카꿀은 만성 비부비동염의 발병과 관련이 있는 Staph- 
ylococcus aureus 에 대한 항균효과 뿐 아니라 비강 세척을 통해 만성 비부비동염의 급성 악화가 있는 환자에 대한 치료 효과가 입증되어 임상적 활용 가능성이 제시되고 있다. ${ }^{16,21)}$ 본 연구를 통해 마누카꿀이 비용 섬유아세포의 근섬유모세 포 분화와 세포외기질 생성을 억제할 수 있음이 확인되었다. 향후 마누카꿀의 임상적 활용을 위해서는 생체 내 실험을 통 한 섬유화 억제 효과의 입증이 필요하며, 만성 비부비동염 발병 억제 효과와 마누카꿀의 국소 비강 치료제로의 활용 가능성을 확인하기 위한 추가적인 연구가 필요할 것이다.

\section{ORCID}

Seung-Heon Shin https://orcid.org/0000-0002-9118-0590

\section{REFERENCES}

1) Stevens WW, Lee RJ, Schleimer RP, Cohen NA. Chronic rhinosinusitis pathogenesis. J Allergy Clin Immunol 2015;136 (6):1442-53.

2) Lechapt-Zalcman E, Coste A, d'Ortho MP, Frisdal E, Harf A, Lafuma $\mathrm{C}$, et al. Increased expression of matrix metalloproteinase- 9 in nasal polyps. J Pathol 2001;193(2):233-41.

3) Watelet JB, Bachert C, Claeys C, Van Cauwenberge P. Matrix metalloproteinases MMP-7, MMP-9 and their tissue inhibitor TIMP-1: Expression in chronic sinusitis vs nasal polyposis. Allergy 2004;59(1):54-60.

4) Wang QP, Escudier E, Roudot-Thoraval F, Abd-Al Samad I, Peynegre $\mathrm{R}$, Coste A. Myofibroblast accumulation induced by transforming growth factor-beta is involved in the pathogenesis of nasal polyps. Laryngoscope 1997;107(7):926-31.

5) Nonaka M, Pawankar R, Fukumoto A, Ogihara N, Sakanushi A, Yagi $\mathrm{T}$. Induction of eotaxin production by interleukin-4, interleukin-13 and lipopolysaccharide by nasal fibroblasts. Clin Exp Allergy 2004; 34(5):804-11

6) Patton T, Barrett J, Brennan J, Moran N. Use of a spectrophotometric bioassay for determination of microbial sensitivity to manuka honey. J Microbiol Methods 2006;64(1):84-95.

7) Al-Waili N, Salom K, Al-Ghamdi AA. Honey for wound healing, ulcers, and burns: data supporting its use in clinical practice. ScientificWorldJournal 2011;11:766-87.

8) Majtan J, Majtan V. Is manuka honey the best type of honey for wound care? J Hosp Infect 2010;74(3):305-6.
9) Leong AG, Herst PM, Harper JL. Indigenous New Zealand honeys exhibit multiple anti-inflammatory activities. Innate Immun 2012; 18(3):459-66.

10) Jervis-Bardy J, Foreman A, Bray S, Tan L, Wormald PJ. Methylglyoxalinfused honey mimics the anti-Staphylococcus aureus biofilm activity of manuka honey: Potential implication in chronic rhinosinusitis. Laryngoscope 2011;121(5):1104-7.

11) Ranzato E, Martinotti S, Burlando B. Honey exposure stimulates wound repair of human dermal fibroblasts. Burns Trauma 2013;1(1): 32-8.

12) Tokunaga $T$, Sakashita M, Haruna $T$, Asaka $D$, Takeno $S$, Ikeda $H$, et al. Novel scoring system and algorithm for classifying chronic rhinosinusitis: The JESREC Study. Allergy 2015;70(8):995-1003.

13) Fokkens WJ, Lund VJ, Mullol J, Bachert C, Alobid I, Baroody F, et al. EPOS 2012: European position paper on rhinosinusitis and nasal polyps 2012. A summary for otorhinolaryngologists. Rhinology 2012;50(1):1-12.

14) Cho JS, Moon YM, Park IH, Um JY, Moon JH, Park SJ, et al. Epigenetic regulation of myofibroblast differentiation and extracellular matrix production in nasal polyp-derived fibroblasts. Clin Exp Allergy 2012;42(6):872-82.

15) Mavric E, Wittmann S, Barth G, Henle T. Identification and quantification of methylglyoxal as the dominant antibacterial constituent of Manuka (Leptospermum scoparium) honeys from New Zealand. Mol Nutr Food Res 2008;52(4):483-9.

16) Alandejani T, Marsan J, Ferris W, Slinger R, Chan F. Effectiveness of honey on Staphylococcus aureus and Pseudomonas aeruginosa biofilms. Otolaryngol Head Neck Surg 2009;141(1):114-8.

17) Lee HM, Kang HJ, Park HH, Hong SC, Kim JK, Cho JH. Effect of peroxisome proliferator-activated receptor gamma agonists on myofibroblast differentiation and collagen production in nasal polypderived fibroblasts. Ann Otol Rhinol Laryngol 2009;118(10):721-7.

18) Haruna $S$, Nakanishi M, Otori N, Moriyama H. Histopathological features of nasal polyps with asthma association: An immunohistochemical study. Am J Rhinol 2004;18(3):165-72.

19) Luo $X$, Deng L, Lamsal LP, Xu W, Xiang C, Cheng L. AMP-activated protein kinase alleviates extracellular matrix accumulation in high glucose-induced renal fibroblasts through mTOR signaling pathway. Cell Physiol Biochem 2015;35(1):191-200.

20) Park IH, Um JY, Hong SM, Cho JS, Lee SH, Lee SH, et al. Metformin reduces TGF- $\beta 1$-induced extracellular matrix production in nasal polyp-derived fibroblasts. Otolaryngol Head Neck Surg 2014;150(1): 148-53.

21) Lee VS, Humphreys IM, Purcell PL, Davis GE. Manuka honey sinus irrigation for the treatment of chronic rhinosinusitis: A randomized controlled trial. Int Forum Allergy Rhinol 2017;7(4):365-72. 